\title{
G跑品 \\ REPORT 78:12
}

CRREL

Repetitive loading tests on membrane-enveloped road sections during freeze-thaw cycles

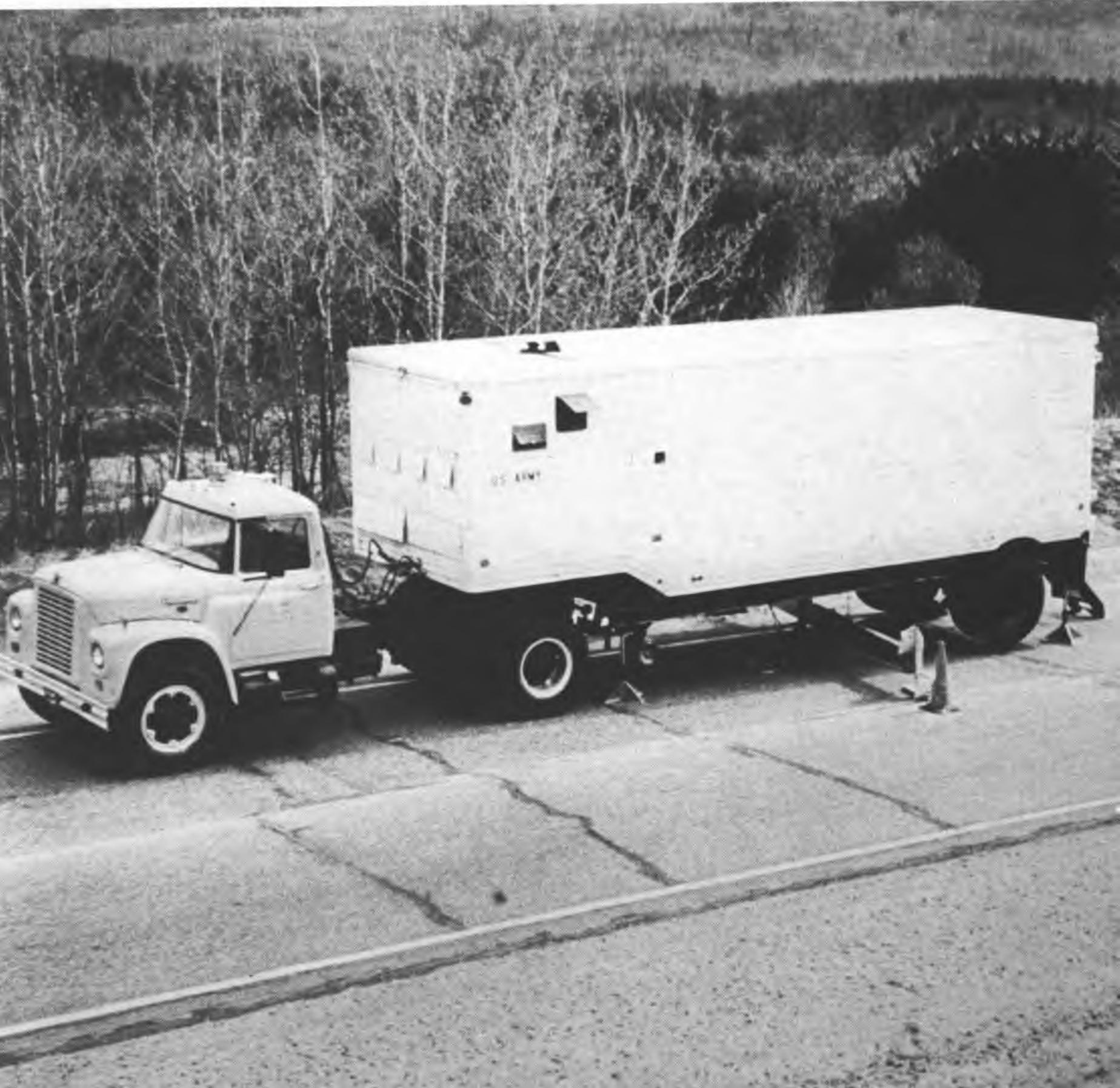




\section{CRREL Report 78-12}

\section{Repetitive loading tests on membrane-enveloped road sections during freeze-thaw cycles}

N. Smith, R.A. Eaton and J.M. Stubstad

May 1978 


\begin{tabular}{|c|c|}
\hline REPORT DOCUMENTATION PAGE & $\begin{array}{c}\text { READ INSTRUCTIONS } \\
\text { BEFORE COMPLETING FORM }\end{array}$ \\
\hline $\begin{array}{l}\begin{array}{l}\text { 1. REPORT NUMBER } \\
\text { CRREL Report } 78.12\end{array} \\
\text { 2. GOVT ACCESSION NO. }\end{array}$ & 3. RECIPIENT'S CATALOG NUMBER \\
\hline $\begin{array}{l}\text { 4. TITLE (and Subtitle) } \\
\text { REPETITIVE LOADING TESTS ON MEMBRANE-ENVELOPED } \\
\text { ROAD SECTIONS DURING FREEZE-THAW CYCLES }\end{array}$ & 5. TYPE OF REPORT A PERIOD COVERED \\
\hline $\begin{array}{l}\text { 7. AUTHOR(s) } \\
\text { N. Smith, R.A. Eaton and J.M. Stubstad }\end{array}$ & 8. CONTRACT OR GRANT NUMBER(D) \\
\hline $\begin{array}{l}\text { 9. PERFORMING ORGANIZATION NAME AND ADDRESS } \\
\text { U.S. Army Cold Regions Research and Engineering Laboratory } \\
\text { Hanover, New Hampshire } 03755\end{array}$ & $\begin{array}{l}\text { 10. PROGRAM ELEMENT, PROJECT, TASK } \\
\text { AREA \& WORK UNIT'NUMBEER ' } \\
\text { DA Project 4A762730AT42 } \\
\text { Task Area A3, Work Unit } 001\end{array}$ \\
\hline \multirow{2}{*}{$\begin{array}{l}\text { 11. CONTROLLING OFFICE NAME AND ADORESS } \\
\text { Directorate of Facilities Engineering } \\
\text { Office, Chief of Engineers } \\
\text { Washington, D.C. } 20314\end{array}$} & $\begin{array}{l}\text { 12. REPORT DATE } \\
\text { May } 1978\end{array}$ \\
\hline & $\begin{array}{l}\text { 13. NUMBER OF PAGES } \\
24\end{array}$ \\
\hline \multirow[t]{2}{*}{ 14. MONITORING AGENCY NAME ADDRESS(It dilferent from Conitrolitind Oflice) } & $\begin{array}{l}\text { 15. SECURITY CLASS. (of thlo report) } \\
\text { Unclassified }\end{array}$ \\
\hline & $\begin{array}{l}\text { 15a. DECLASSIFICATION/DOWNGRADING } \\
\text { SCHEOULE. }\end{array}$ \\
\hline
\end{tabular}

16. DISTRIBUTION STATEMENT (of this Report)

Approved for public release; distribution unlimited.

17. DISTRIBUTION STATEMENT (of the abstract entered in Block 20, if ditferent from Report)

18. SUPPLEMENTARY NOTES

$\begin{array}{ll}\text { 19. KEY WOROS (Continue on reverse side if necessary and fdentify by block number) } \\ \text { Clay } & \text { Roads } \\ \text { Cold regions } & \text { Silt } \\ \text { Engineering } & \text { Soil mechanics } \\ \text { Freezing } & \text { Soils } \\ \text { Highways } & \text { Strength (mechanics) }\end{array}$

20. ABSTRACT (Continue on roverae side If necessary and Identlfy by biock numbor)

Road test sections of membrane-enveloped silt and clay soils overlain with asphalt cement concrete were subjected to repetitive dynamic plate-bearing loadings to determine their strength variations during freeze-thaw cycles. The recoverable surface deformations in the load deflection bowl were continuously measured during the loading cycles and analyzed using the Chevron layered elastic computer program to obtain the in situ resilient deformation modulus of the various section layers at different stages of the freeze-thaw cycles. The resilient stiffness of the pavement system (the total load per unit of resilient load plate deflection) was also calculated for the various freeze-thaw conditions. The modulus values of the asphalt cement concrete varied inversely with its temperature by an order of magnitude $(90,000$ psi to $1,300,000 \mathrm{psi})$. The resilient stiffness of the pavement system varied in the same manner by nearly a 
20. Abstract (cont'd)

factor of eight (228.4 kips/in. to $1740.2 \mathrm{kips} / \mathrm{in}$.). Despite the wide strength variations of the sections during freeze-thaw cycles, membrane-enveloped fine-grained soils can be utilized instead of granular materials as base and subbase layers in flexible pavements in cold regions where moisture migration is a major concern. Moisture migration did not occur at saturation levels up to $75 \%$; thus there was no strength loss during thawing. 


\section{PREFACE}

This report was prepared by North Smith and Robert A. Eaton, Research Civil Engineers, and John M. Stubstad, Mechanical Engineer, of the Northern Engineering Research Branch, Experimental Engineering Division, U.S. Army Cold Regions Research and Engineering Laboratory. The research was sponsored by the Office, Chief of Engineers, under DA Project 4A762730AT42, Design, Construction and Operations Technology for Cold Regions, Task Area A3, Facilities Technology/Cold Regions, Work Unit 001, Use of Frost Susceptible Soils in Roads and Airfields.

The authors wish to express their appreciation to John A. Ricard and Glenn D. Durell for conducting the field tests and to T. David Reese and Margaret March for data reduction and analysis: The report was technically reviewed by Edward F. Lobacz and Thaddeus C. Johnson of CRREL.

The contents of this report are not to be used for advertising or promotional purposes. Citation of brand names does not constitute an official endorsement or approval of the use of such commercial products. 
Abstract ......

Preface

Conversion factors: U.S. customary to metric units of measurement .

Introduction

Freeze-thaw system

Construction materials .

Controlled environment test section

Outdoor sections

Temperature monitoring instrumentation

Repetitive plate bearing test apparatus

Test results and analyses

Conclusions

Literature cited

\section{ILLUSTRATIONS}

Figure

1. Typical MESL section

2. Plan and profile views of access road .....................................................................

3. Refrigeration-heating system ...............................................................................

4. Heat transfer panel ...........................................................................................

5. Grain size distribution and compaction curves for concrete sand and encapsulated silt 4

6. Frozen in-situ moistures and densities in controlled Moulton pit silt MESL ................ 5

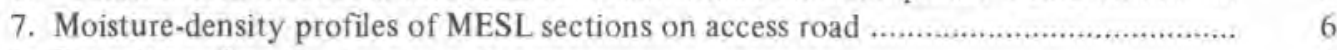

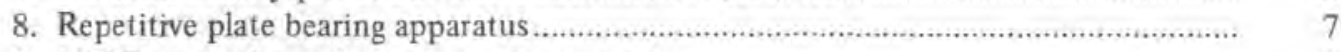

9. LVDT set-up for deformation measurements ….................................................... 8

10. Typical measured and computed resilient surface deformations of silt MESL,............ $\quad 9$

11. Variation of resilient deformation stiffness with thaw depth in Moulton pit silt MESL paved with AC-20 asphalt concrete during thawing

12. Variation of resilient deformation stiffness during thaw and recovery period for Moulton pit silt MESL paved with AC-1.5 asphalt concrete ................................ 9

13. Benkelman beam deflections on Moulton pit silt MESL ......................................... 11

14. Variation of resilient deformation modulus of asphalt cement concrete with temperature 13

15. Variation of resilient deformation modulus of thawed silt MESL layer with thickness 15

16. Variation of resilient deformation modulus of frozen silt MESL layer with temperature 15

\section{TABLES}

Table

I. Resilient surface deformation and resilient deformation stiffness of Moulton pit silt MESL test section - first freeze-thaw cycle

II. Resilient surface deformation and resilient deformation stiffness of Moulton pit silt MESL test section - second freeze-thaw cycle

III. Resilient surface deformations and resilient deformation stiffness of access road MESL lest sections

IV. Resilient deformation moduli for Moulton pit silt MESL test section - first freeze-thaw cycle

V. Resilient deformation moduli for Moulton pit silt MESL test section - second freezethaw cycle

VI. Resilient deformation moduli for access road MESL tests sections 
CONVERSION FACTORS: U.S. CUSTOMARY TO METRIC (SI) UNITS OF MEASUREMENT

These conversion factors include all the significant digits given in the conversion tables in the ASTM Metric Practice Guide (E 380), which has been approved for use by the Department of Defense. Converted values should be rounded to have the same precision as the original (see E 380).

\begin{tabular}{|c|c|c|}
\hline Multiply & By & To obtain \\
\hline inch & $25.4 *$ & millimeter \\
\hline foot & $0.3048^{*}$ & meter \\
\hline $\operatorname{yard}^{2}$ & 0.8361274 & meter $^{2}$ \\
\hline foot ${ }^{3}$ & 0.02831685 & meter ${ }^{3}$ \\
\hline gallon & 0.003785412 & meter $^{3}$ \\
\hline pound force & 4.448222 & newton \\
\hline pound/inch ${ }^{2}$ & 6894.757 & pascal \\
\hline pound $/$ foot ${ }^{3}$ & 16.01846 & kilogram $/$ meter $^{3}$ \\
\hline Btu & 1055.056 & joule \\
\hline degrees Fahrenheit & $t_{\mathrm{K}}=\left(t_{\mathrm{o}_{\mathrm{F}}}+459.67\right) / 1.8$ & kelvins \\
\hline
\end{tabular}

* Exact 


\section{REPETITIVE LOADING TESTS ON MEMBRANE-ENVELOPED ROAD SECTIONS DURING FREEZE-THAW CYCLES}

\author{
N. Smith, R.A. Eaton and J.M. Stubstad
}

\section{INTRODUCTION}

The U.S. Army Cold Regions Research and Engineering Laboratory (CRREL) in Hanover, New Hampshire, has been conducting controlled environment freeze-thaw experiments on membrane-enveloped road test sections for the past several years. The test facility and associated experimental equipment were described in detail by Eaton et al..$^{5}$

During the same time period, several types of road test sections have been constructed and monitored for performance throughout the year in an outside environment. The construction and performance of an experimental access road at CRREL in Hanover and a road test section near Fairbanks, Alaska, were documented by Berg and Eaton ${ }^{2}$ and Smith and Pazsint. "

The objective of this paper is to present the results and analyses of repetitive plate bearing tests conducted on a silt MESL (membrane-enveloped soil layer) road test section (Fig. 1) during two freeze-thaw cycles in the controlled environment facility and on three silt MESL test sections in the CRREL access road (Fig. 2) during a winter and spring freeze-thaw period. Two of the three access road test sections have additives mixed with the silt - sodium chloride in one and lime with flyash in the other. The third test section has plain silt,

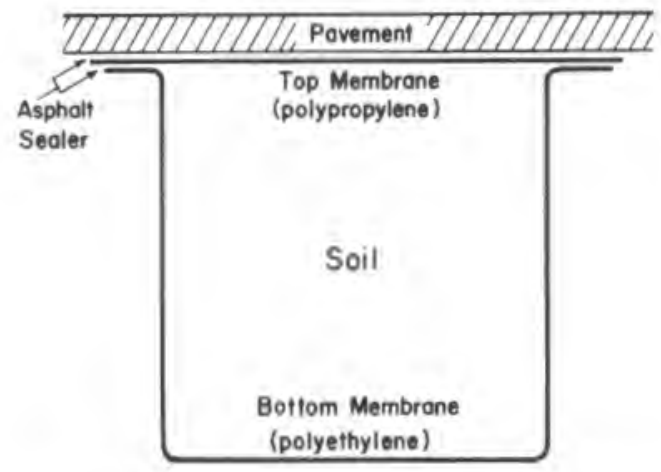

Figure 1. Typical MESL (membrane-enveloped soll layer) section (not to scale). as does the section in the controlled environment facility, An additional section on the aecess road containing silt with lime and flyash without a membrane envelope pro. vides comparative data on open system freezing and thawing strengths.

The use of membranes to preserve the high strength of fine-grained soils compacted at optimum or slightly below optimum moisture content is well established for non-frost environments. ${ }^{3}{ }^{14}$ The questions concerning moisture migration during freezing and subsequent strength loss during thawing in such systems have only partially been answered by laboratory experiments. ${ }^{1} 89$ to These full-scale test results demonstrate further the viability of the membrane envelope concept and provide additional data for the development of a rational design method for flexible pavements using this concept in cold regions.

\section{FREEZE-THAW SYSTEM}

A controllable rate of frost and thaw penetration is provided by a special refrigeration-heating unit (Fig, 3). The system can simulate freezing and thawing cycles, the reby allowing completion in weeks or months of pavement testing that would require years under natural conditions. Natural freezing and thawing conditions at the pavement surface can be simulated on a yearly or daily basis. It is also possible to interrupt the progression of freezing or thawing at any particular depth to allow testing of the pavement.

The pavement is heated or cooled by placing heat transfer panels (Fig. 4 ) on the surface of a test section that has been covered with a thin layer of wet sand to ensure intimate thermal contact. A 50/50 solution of ethylene glycol and water is the working medium that transfers heat between the panels and the refrigeration. heating unit. A two-stage semi-hermetic compressor provides a total refrigeration capacity of $29,000 \mathrm{Btu} / \mathrm{hr}$ at a $-45^{\circ} \mathrm{F}$ evaporator temperature. For thawing, the solution is heated by a $21-\mathrm{kW}$ electric immersion heater. 


\begin{tabular}{|c|c|c|c|c|c|c|c|}
\hline & & +30 & || $\mid \quad 4 \div 40$ & 11 & $2+50$ & & ت \\
\hline $24^{\prime}$ (1) & $\begin{array}{l}\text { West } \\
\text { East }\end{array}$ & (G) - & \begin{tabular}{|l|l|} 
& $\frac{a}{b}$ \\
\end{tabular} & $\mathrm{D}_{2}$ & $D_{1}$ & (C) (B) & (A) \\
\hline
\end{tabular}

\section{P L A N}

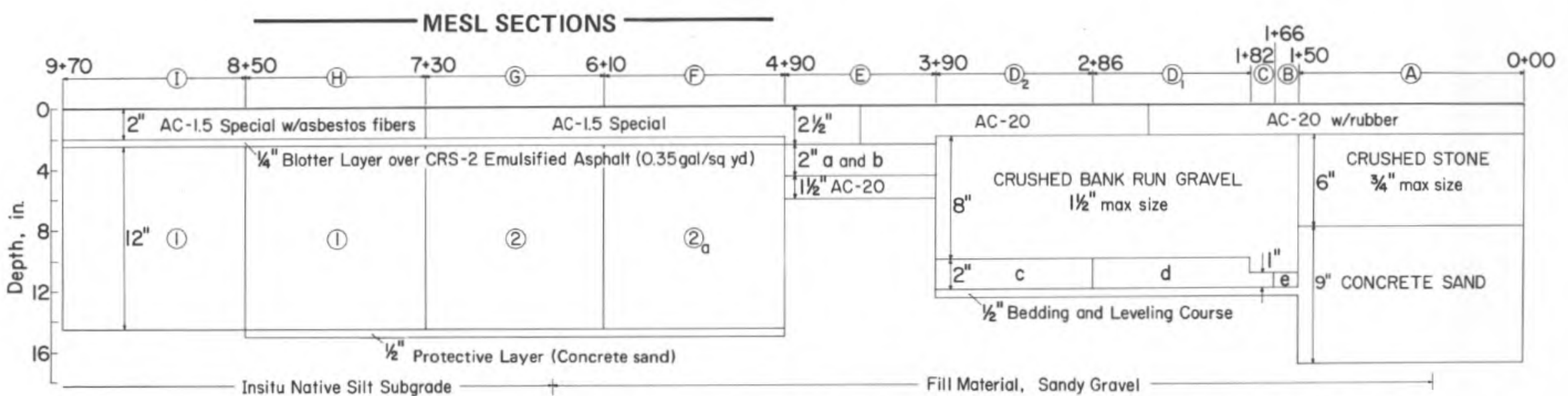

S (1) Mixed with $6 \%$ Flyash and $3 \%$ Lime by weight (6.6 lbs/cu ft Flyash and $3.3 \mathrm{lbs} / \mathrm{cuft}$ Lime)

(2) Plain Silt (2) Silt mixed with Salt, $6 / 4 \mathrm{lb}$ Salt/100 lbs (I cu ft) of Silt

Material encapsulated in Polyethylene Plastic $(6 \mathrm{mil})$, sides and bottom. Top covered with Polypropylene Fabric, non-woven ( 5 deniere wt) over loyer of CRS-2 Emulsified Asphalt (West half: $0.4 \mathrm{gol} / \mathrm{sq} \mathrm{yd}$, East half: $0.3 \mathrm{gal} / \mathrm{sq} \mathrm{yd}$ )

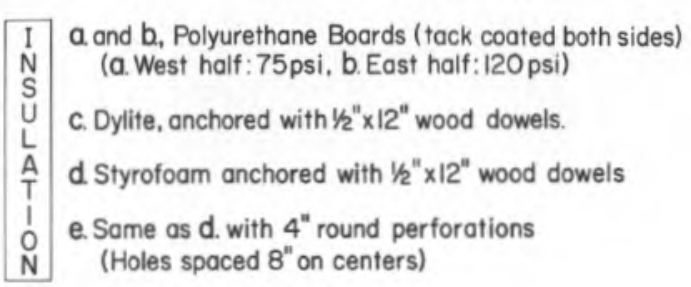

and b. Polyurethane Boards (tack coated both sides) (a. West half: 75 psi, b. East half: 20 psi)

ASPHALT CONCRETE

\section{S E C T I O N}

Figure 2. Plan and profile views of access road. 


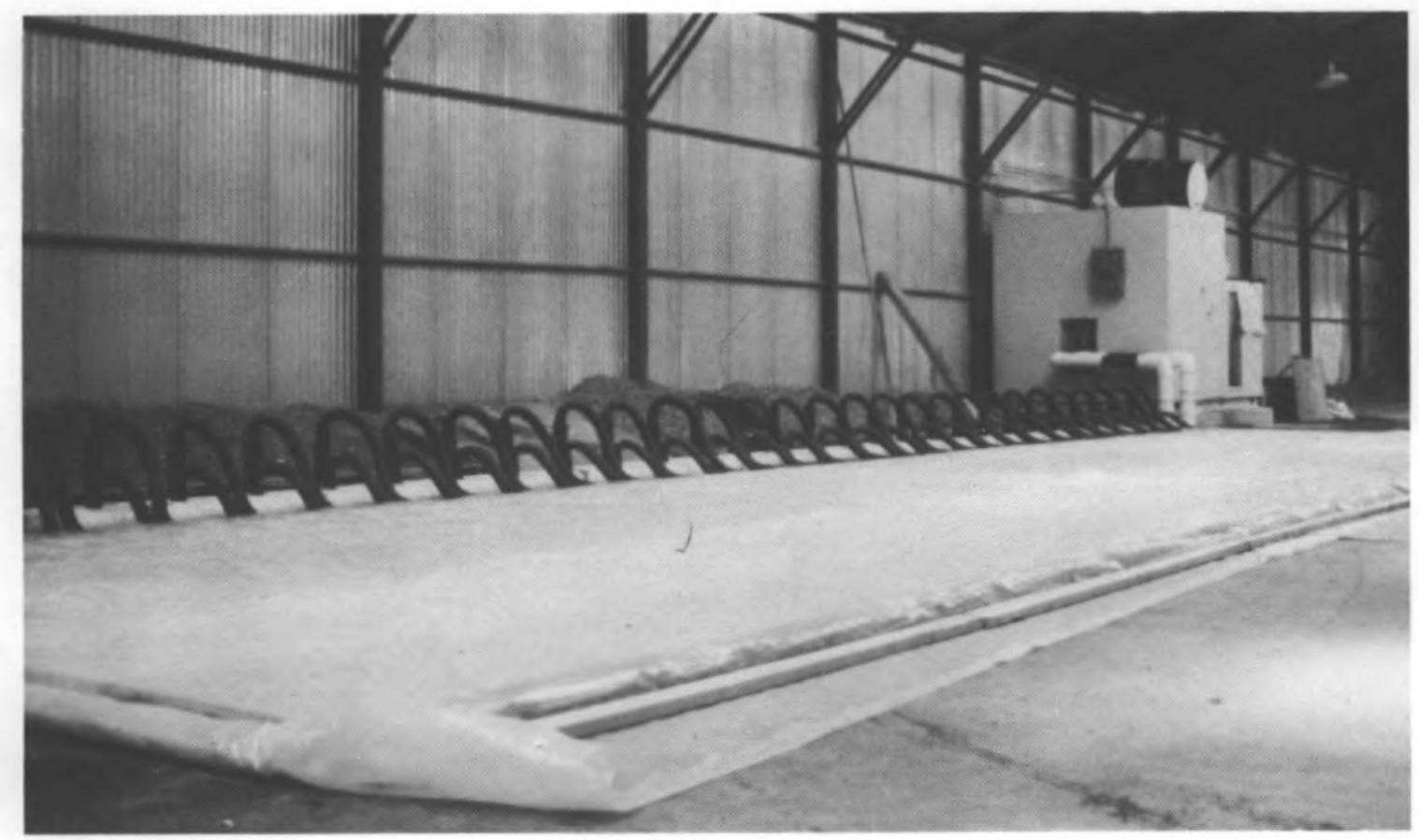

Figure 3. Refrigeration-heating system.

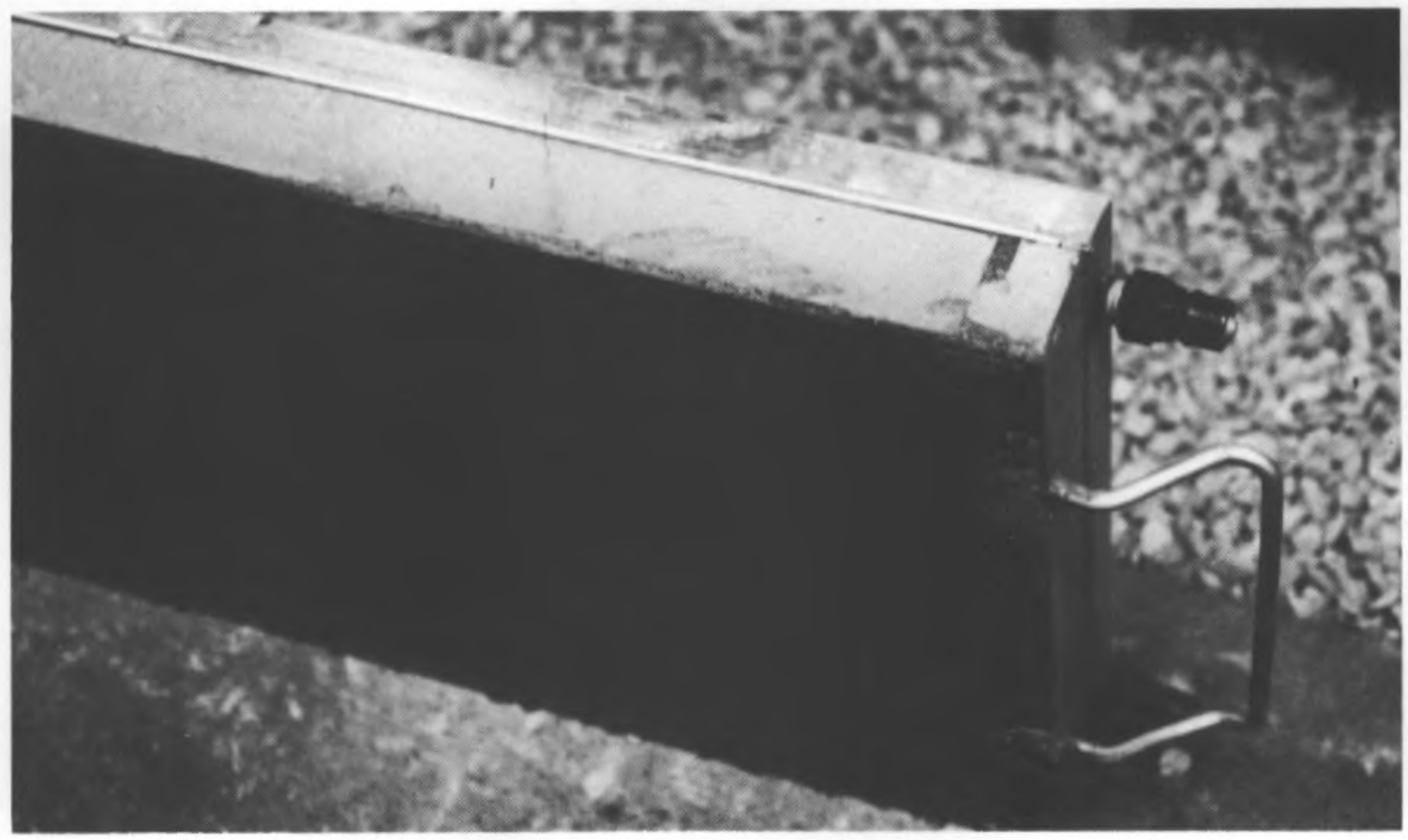

Figure 4. Heat transfer panel. 
U.S. Std. Sieve Size

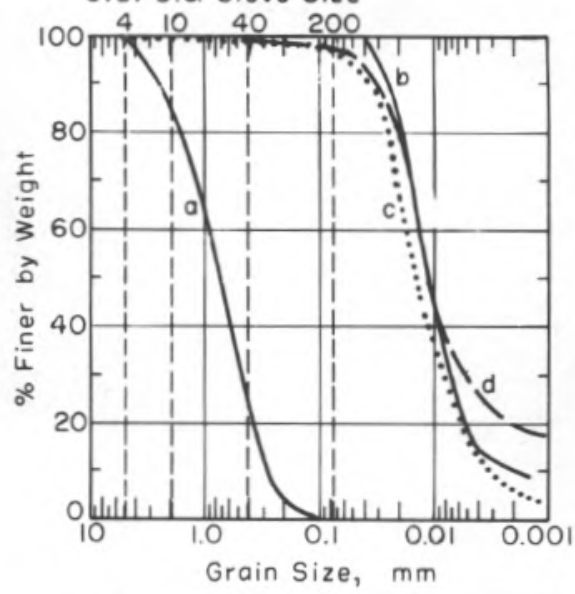

\begin{tabular}{c|c|c|c|}
\hline & \multicolumn{2}{|c|}{ Sand } & \multirow{2}{*}{ Silt or Clay } \\
\hline \multicolumn{1}{|c|}{$\mid$ Med } & Fine & \\
\hline Coarse
\end{tabular}
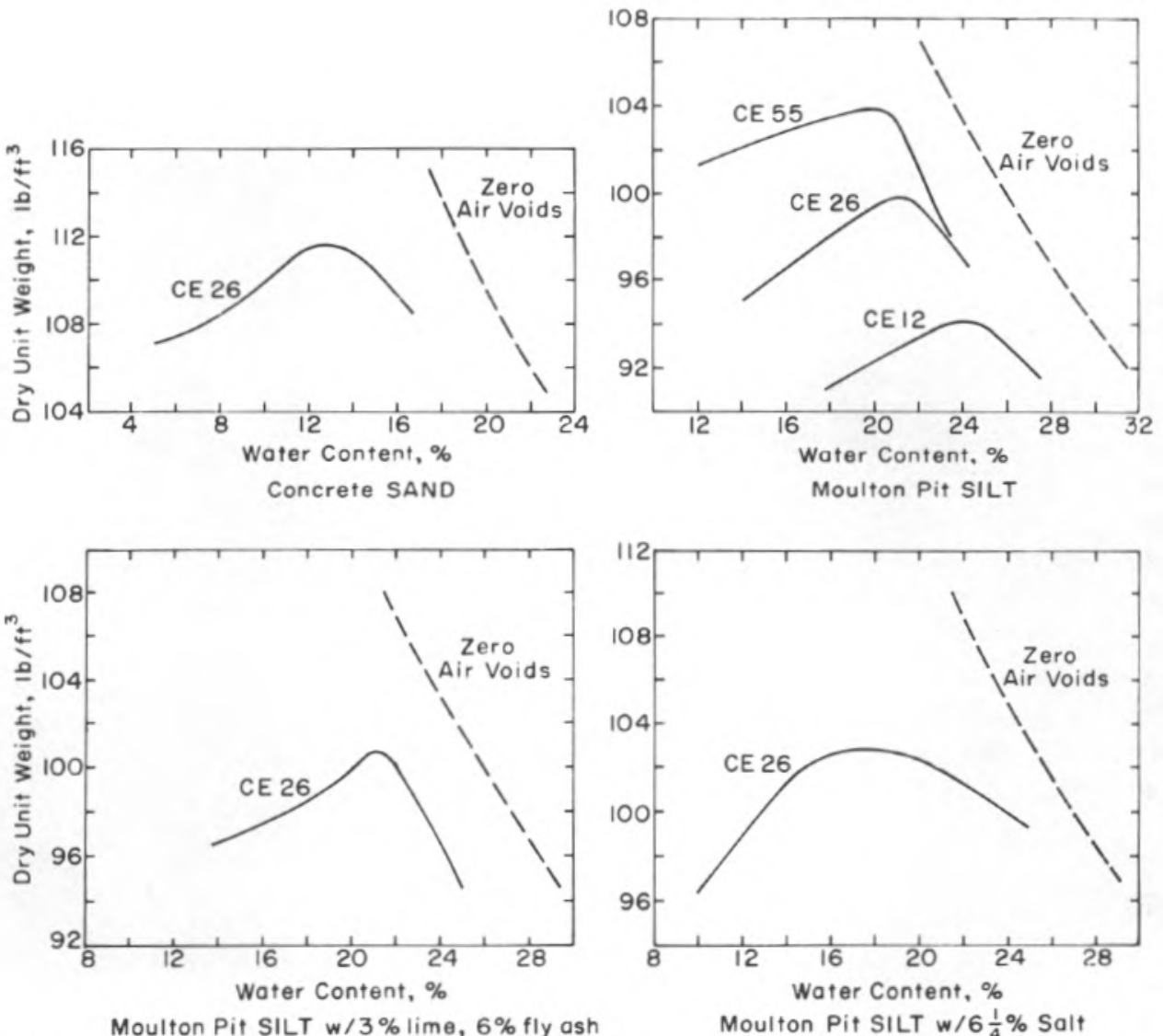

Figure 5. Grain size distribution and compaction curves for concrete sand and encapsulated silt. 


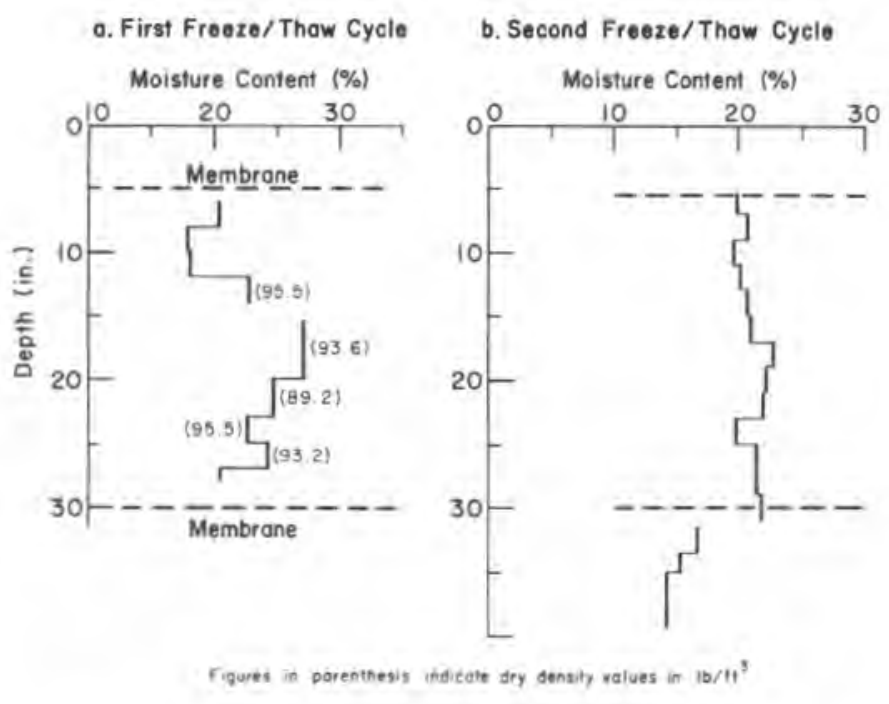

Figure 6. Frozen in-situ moistures and densities in controlled Moulton pit silt MESL.

Temperatures across the bottom surfaces of the panels vary no more than $3^{\circ} \mathrm{F}$ for either mode. The solution is circulated by a 5 -hp impeller pump.

The unit has two types of temperature control, set point and programmable. In the set point mode, the unit maintains the specific set temperature by alternately heating and cooling. In the programmable mode, a cam-type temperature programmer regulates panel temperatures as a function of time. Cam programs simulating daily fluctuations or long-term variations in surface temperature are possible. The programmer unit is also equipped with hold and reset capabilities to permit lesting during a freeze or thaw cycle.

These temperature control capabilities allow 1 ) very slow frost penetrations, which allow the greatest amount of moisture to be drawn to the freezing front (a very adverse frost heaving situation), or 2) rapid frost penetration for quick freezing of materials with limited moisture migration and heave. Five to six freeze-thaw cycles per year (including testing) to depths up to 4 feet are possible with this equipment, depending on soil properties and moisture contents.

\section{CONSTRUCTION MATERIALS}

\section{Controlled environment test section}

A $12 \times 20 \times 3$-foot-deep silt MESL section was constructed using 6-mil polyethylene as a waterproofing membrane. The silt was placed in approximately 6 -inch layers, each of which was compacted with a 10-ton tandem-wheeled steel roller and hand-operated vibra. tory compactor. The polyethylene membrane was folded over the top surface and covered with a poly. propylene membrane to give added protection during paving with two 2-inch courses of AC-20 asphalt cement concrete. ${ }^{13}$ The grain size distribution and compaction curves for the silt are shown in Figure 5. The moisture and density measurements for completely frozen soil core samples obtained during the first and second freeze-thaw cycles are shown in Figure 6.

The compaction control test used by the U.S. Army Corps of Engineers ${ }^{4}$ is the modified version of AASHO (American Association of State Highway Officials) method T180, and conforms entirely to ASTM (American Society for Testing and Materials) designation D1557. The Corps-designated CE-55 test consists of 55 blows per layer on each of five layers with a 10-1b hammer falling 18 inches. In developing relationships for density and CBR (Califomia Bearing Ratio) with moisture content at lesser compactive efforts the $\mathrm{CE}$ 12 and CE-26 ( 12 and 26 blows per layer) compaction tests are conducted.

\section{Outdoor sections}

Three MESL road test sections were constructed in the CRREL access road using silt from the same source. Two of the sections had additivies mixed with the silt (6x) NaCl in one and $3 \%$ lime with $6 \%$ flyash in the other) to evaluate their potential to retard freezing and moisture migration during freezing. Gradation curves and laboratory properties of the silt with the additives are shown in Figure 5. A thin layer (about $1 / 2$ inch) of concrete sand (Fig. 5) was spread on the bank run gravel before the polyethylene membrane was placed. The moisture and density measurements from frozen soil tore samples of these sections are shown in Figure 7. 

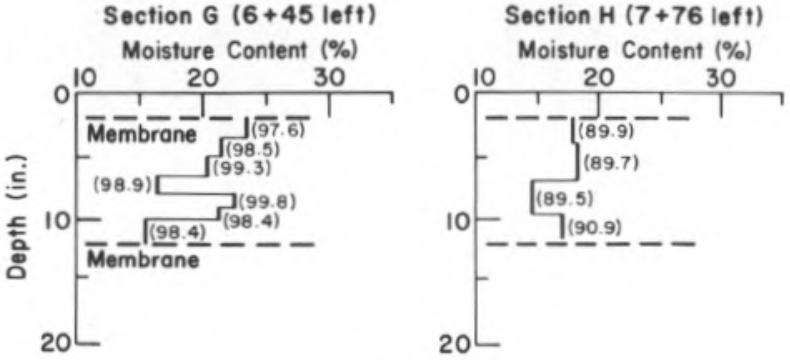

Section I $(8+55$ left $)$ Moisture Content (\%)

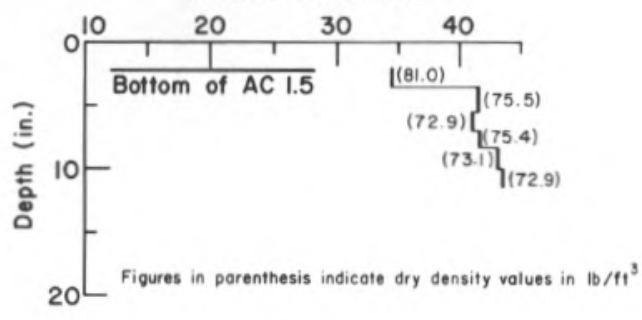

a. 1974.

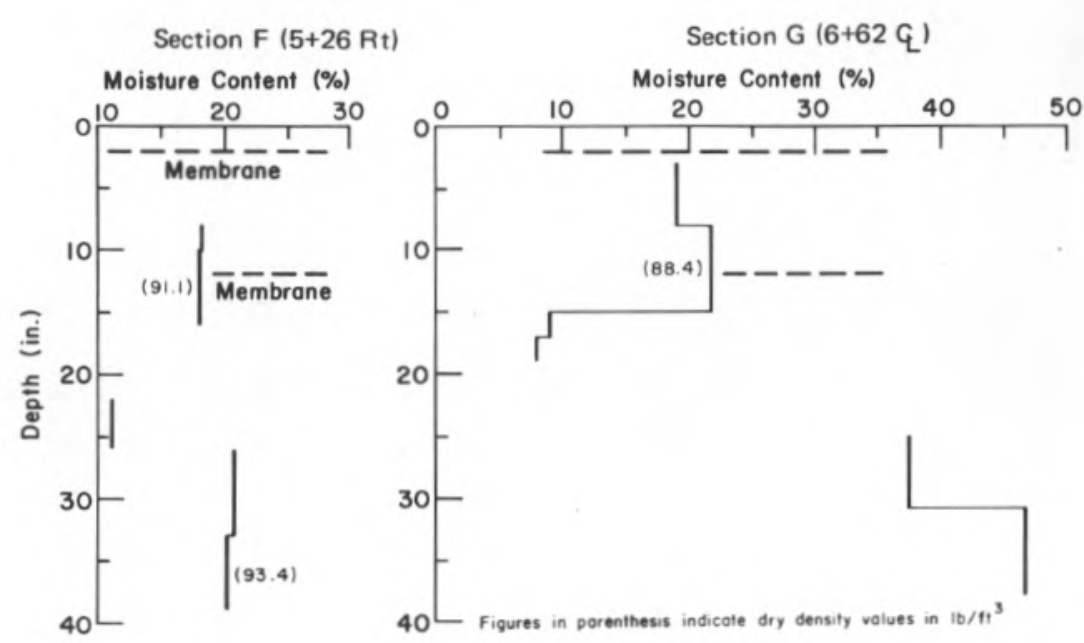

b. 1976 .
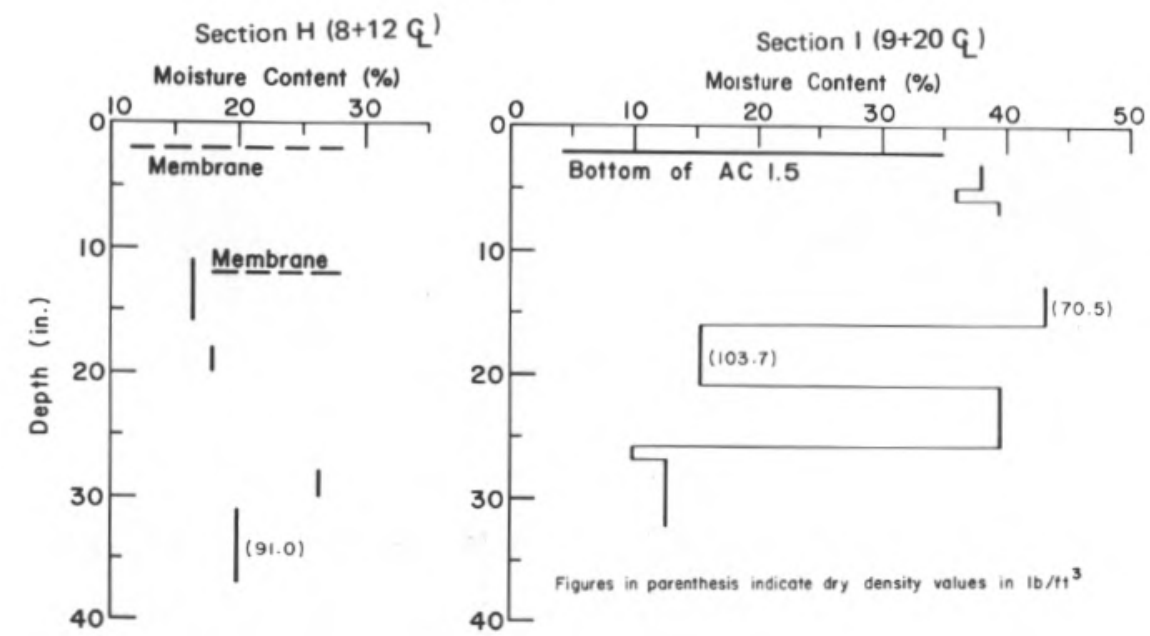

c. 1976.

Figure 7. Moisture-density profiles of MESL sections on access road. 


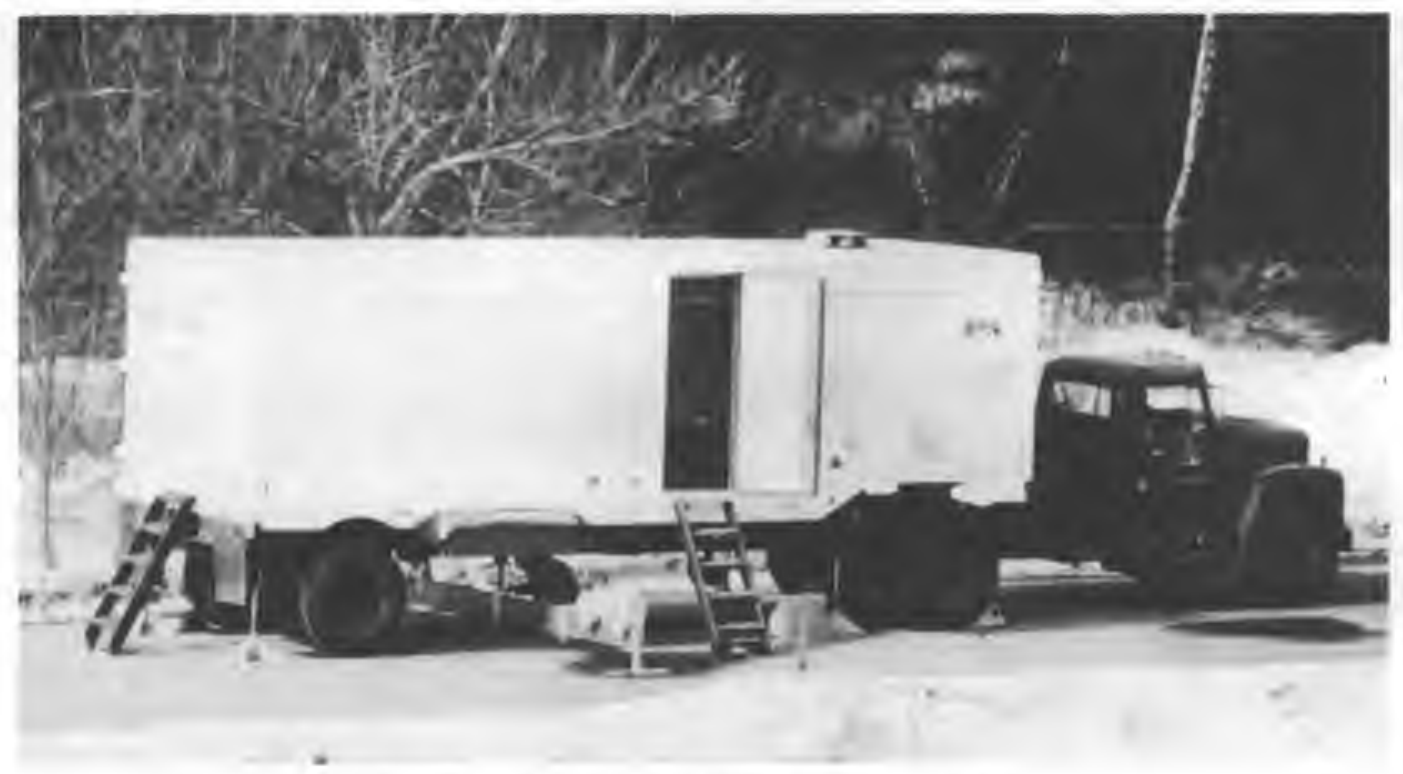

Figure 8. Repetitive plate bearing apparatus.

\section{TEMPERATURE MONITORING INSTRUMENTATION}

Copper-constantan thermocouples were installed in the test sections after the encapsulated soil was in place and prior to placement of the top membrane. Two vertical arrays were placed in each section in soil core sampling holes. Spacings for the thermocouples were such that the location of the $32^{\circ} \mathrm{F}$ isotherm could be determined during the freezing and thawing of the section. For the controlled environment sections, adjustments to the refrigeration unit to provide the required freezing rate (about 1 inch/day) were determined by the thermocouple readings. An automatic recorder sampled the thermocouple outputs at preselected intervals.

\section{REPETITIVE PLATE BEARING (RPB) TEST APPARATUS}

The CRREL repetitive plate bearing test vehicle (Fig. 8) is a self-contained, trailer-mounted pavement testing apparatus which is capable of conducting repetitive plate bearing tests on roads and airfields with a minimum of set-up and take-down time. The trailer, which has a gross weight of 36,000 pounds, is 27 feet long, 12 feet high and 8 feet wide. The axle load of the trailer has been designed to be 18,000 pounds so that this vehicle can also be employed to conduct standard Benkelman beam static rebound tests.
Power requirements are supplied by a $7.5-\mathrm{kW}, 120 /$ 240-volt electric generator driven by an air-cooled gasoline engine installed inside the trailer. Hydraulic rams located at each corner of the trailer are used to lift the trailer wheels off the test surface. Each ram has an 18-inch-square aluminum foot plate which is connected to the ram via a removable pin.

The plate bearing load actuator is a two-chamber pneumatic-hydraulic pressure transformer. To generate the plate bearing load pulse, an air pressure pulse of approximately $80 \mathrm{psi}$ is supplied to the upper chamber. The lower chamber, which is filled with ethylene glycol, converts this pressure pulse into a 9000 -pound-force pulse. A load cell installed between the lower chamber and the load plate provides a continuous readout of the force transmitted.

A $14.4-\mathrm{ft}^{3} / \mathrm{min}$ two-stage air compressor driven by an electric motor supplies compressed air for the load actuator. A two-way air control valve actuated by a solenoid generates the compressed air pressure pulse. A solid state timer regulates the motion of the air control valve. The timer circuit is adjustable to allow variation in the duration of the pressure pulse and the elapsed time between pulses. The duration is continuously adjustable between 0.2 and 20 seconds. The elapsed time between pulses is also continuously adjustable between 30 repetitions per minute and 1 repetition every 3 minutes. The number of load pulses during the test is automatically recorded.

Flow restrictors with adjustable needle valves installed in the supply and exhaust lines of the load 


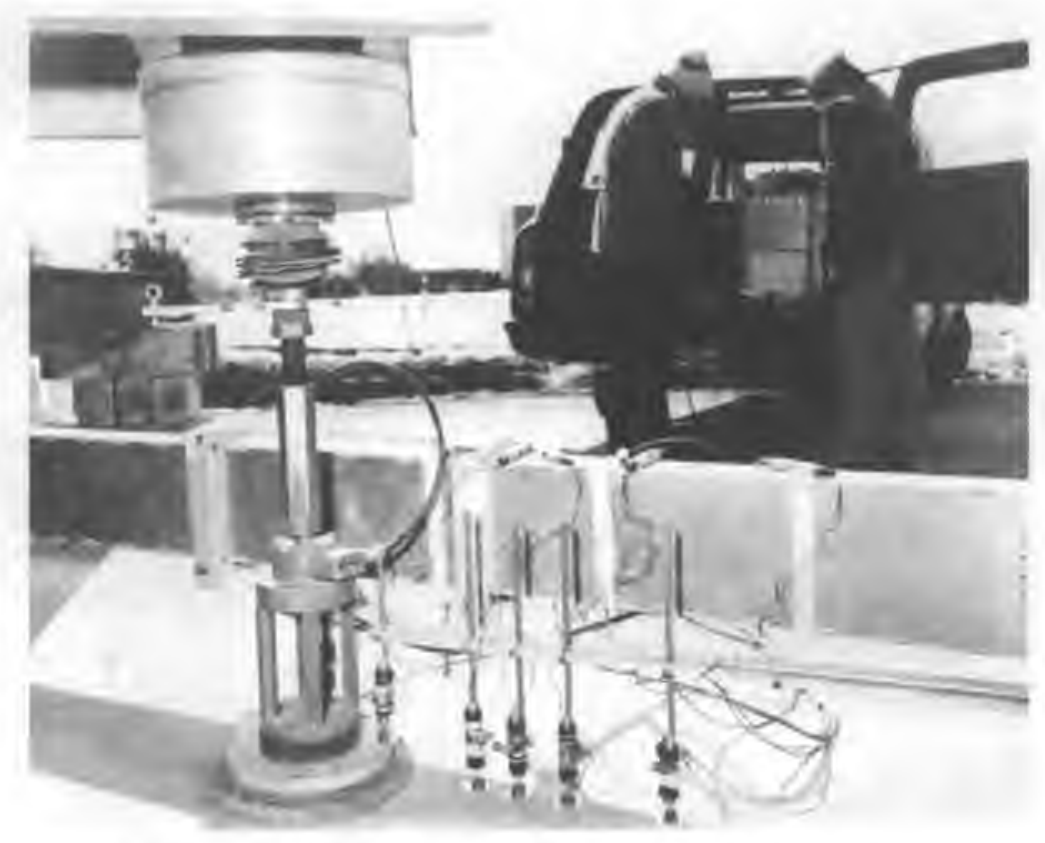

Figure 9. LVDT sel-up for deformation measurements.

actuator allow adjustment of the rate of pressure rise and pressure release of the load actuator. This adjustment is needed to enable a standardized load pulse to be used at test sites with different response stiffnesses.

Linear variable differential transformers (LVDT's) are used to monitor the motion of the 12-inch-diameter load plate and the surface deflection basin. The dc-type LVDT's are mounted to an 18-foot reference beam and are positioned with two on the load plate on perpendicular radii and four in the surface deflection basin aligned with one of the plate LVDT's (Fig. 9). A strip-chart recorder monitors the LVDT and load cell outputs.

\section{TEST RESULTS AND ANALYSES}

The resilient surface deformations after 500 load repetitions were used in the elastic layer analysis. The resilient stiffness values were calculated for the entire pavement system using the load in kips and the resilient plate deflection in inches after 500 load repetitions. Surface deformation and calculated stiffness are presented in Tables I-III.

Using the Chevron 5-layer elastic analysis? 12 is the resilient deformation modulus of each pavement layer was determined by trial and error. Computed moduli are presented in Tables IV-VI. The thicknesses of the various pavement layers for each thaw condition along with the test load constituted the input data. Trial moduli based on past experience and published reports of similar tests were used to calculate surface deformations at the radii of field-measured resilient surface deformations. Usually, after 20 to 30 trials there was good agreement between the measured and calculated resilient surface deformations, meaning that the correct moduli had been determined. For these calculations the Poisson's ratio values were assumed constants, usually ranging from 0.35 for frozen materials to 0.4 for thawed.

The resilient deformation moduli determined by trial and error produced computed surface deflections within $\pm 5 \%$ of the measured values except in a few instances where the measured values were suspect. Figure 10 shows the typical trend of measured and computed surface deflections during a freeze-thaw cycle. The Chevron program used in these analyses was limited to a five-layer system with layer thickness being selected to match thaw conditions. In general, the first soil layer under the asphalt cement concrete has to be a thinner, weaker layer than like material deeper in the section to match the measured deflections. Typically the five-layer system consists of the asphalt cement concrete, two thawed layers for deep thaw, a frozen layer, and the subgrade.

Figure 11 illustrates the nearly six-fold decrease in the resilient deformation stiffness as the controlled test sections changed from frozen to thawed. Figure 12 shows a similar trend for the outdoor MESL sections except for the sodium chloride stabilized section which 

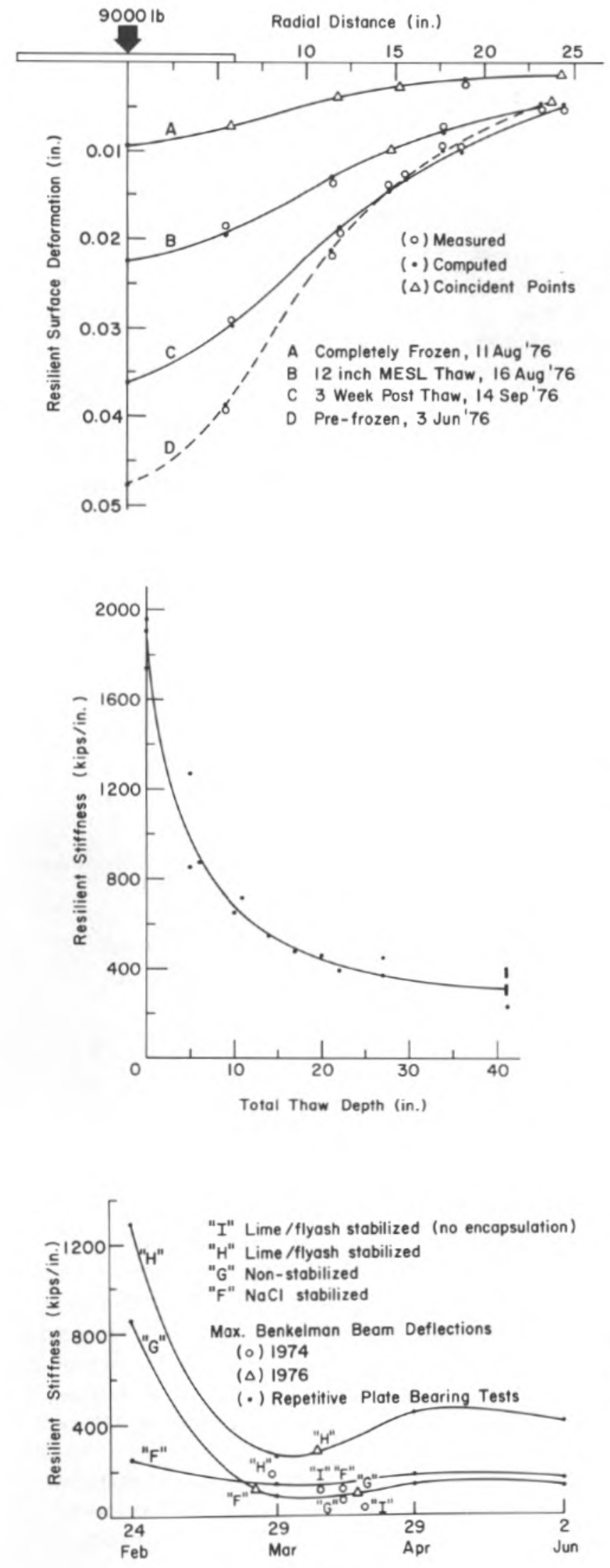

1976
Figure 10. Typical measured and computed resilient surface deformations of silt MESL.

Figure 11. Variation of resilient deformation stiffness with thaw depth in Moulton pit silt MESL paved with AC-20 asphalt concrete during thawing.
Figure 12. Variation of resilient deformation stiffness during thaw and recovery period for Moulton pit silt MESL paved with AC-1.5 asphalt concrete (access road). 
Table I. Resilient surface deformations and resilient deformation stiffness of Moulton pit silt MESL test section - first freeze-thaw cycle.

\begin{tabular}{|c|c|c|c|c|c|c|c|}
\hline \multirow{2}{*}{$\begin{array}{l}\text { Freeze thaw conditions } \\
\text { Before freezing }\end{array}$} & \multirow{2}{*}{$\begin{array}{c}\begin{array}{c}\text { Load } \\
(I b)\end{array} \\
9125\end{array}$} & \multicolumn{5}{|c|}{ Deformation (in.) - Otfset from center of 12-in.-diam load plate (in.) } & \multirow{2}{*}{$\begin{array}{r}\begin{array}{r}\text { Resilien } \\
\text { stifymess } \\
\text { (kips/in. }\end{array} \\
310.4\end{array}$} \\
\hline & & $0.0294-6.0^{*}$ & 0.0219 .11 .75 & $0.0179-15.0$ & $0.0149 \cdot 18.25$ & $0,0098-24,0$ & \\
\hline Before freezing & 9500 & $0.0262-5.75$ & $0.0186-12.5$ & 0.0154 .15 .5 & $0.0128-18.75$ & $0.0091-21.25$ & 362.6 \\
\hline Completely frozen & 8750 & $0.0046-5.25$ & $0.0033-1 ! .5$ & $0.0026-14.5$ & $0.0023-17.75$ & $0,0019.23 .5$ & 1902.2 \\
\hline Completely frozen & 9000 & $0.0046-5.375$ & $0.0030-10.5$ & $0.0024-13.75$ & $0.0020-16.75$ & $0.0016-22.5$ & 1956.5 \\
\hline Completely frozent & 9375 & 0.0110 .5 .5 & $0.0060-10.5$ & $0.0046-13.75$ & 0.0037 .16 .75 & $0.0025-23.0$ & 852.3 \\
\hline 6-in. MESL thaw & 9000 & $0.0126-5.5$ & 0.0087 .11 .5 & $0.0066-14.75$ & 0.0057 .17 .75 & $0.0037-23.75$ & 714.3 \\
\hline 9-in. MESL thaw & 9000 & $0.0165-5.5$ & $0.0110-11.0$ & 0.0079 .14 .25 & $0.0066-17.5$ & $0.0041-23.25$ & 545.4 \\
\hline 12 in. MESL thaw & 8875 & $0.0183-5.5$ & $0.0127-11.5$ & $0.0095-14.25$ & $0.0081-17.125$ & $0.0052-23.375$ & 485.0 \\
\hline 15-in. MESL thaw & 8875 & $0.0195 \cdot 5.5$ & $0.0135-11.25$ & $0.0103-14.25$ & $0.0084-17.125$ & $0.0050 \cdot 23.375$ & 455.1 \\
\hline 22-in. MESL thaw & 9000 & $0.0199-5.75$ & $0.0147-10.25$ & & $0,0101-16.5$ & $0.0068-22.5$ & 452.3 \\
\hline Complete MESL thaw & 8875 & $0.0248-5.25$ & $0.0175-11.0$ & $0.0129-14.5$ & $0.0108-17.25$ & $0.0069-23.25$ & 357.9 \\
\hline 1 wk after thawing & 9000 & 0.0229 .5 .5 & $0.0164-11.25$ & $0.0127-14.25$ & $0.0106-17.25$ & $0.0070-23.25$ & 390.0 \\
\hline
\end{tabular}

- Example: 0.0294 in. deformation -6.0 in. offset.

$+\mathrm{AC}-20$ above $32^{\circ} \mathrm{F}$.

Table II. Resilient surface deformations and resilient deformation stiffness of Moulton pit silt MESL test section - second freeze-thaw cycle.

\begin{tabular}{|c|c|c|c|c|c|c|c|}
\hline \multirow{2}{*}{$\begin{array}{l}\text { Freese-tha w conditions } \\
\text { Before freezing }\end{array}$} & \multirow{2}{*}{$\begin{array}{c}\text { Load } \\
\text { (lb) }\end{array}$} & \multicolumn{5}{|c|}{ Deformation (in.) - Offser from center of 12-in.diam load plate (in.) } & \multirow{2}{*}{$\begin{array}{c}\begin{array}{c}\text { Resilient } \\
\text { stiffness } \\
\text { (kips/in.) }\end{array} \\
228.4\end{array}$} \\
\hline & & $0.0394-5.5$ & $0.0219-11.5$ & $0.0143-14.75$ & 0.0097 .17 .75 & $0.0046-23,75$ & \\
\hline Complefely frozen & 9000 & $0.0051-5.375$ & $0.0030-10.5$ & $0.0023-13.75$ & $0.0021-16.75$ & $0.0016-22.5$ & 3740.2 \\
\hline Completely frozen & 9000 & $0.0071+5.75$ & $0.0040-11.75$ & $0,0029-15,25$ & $0.0024-19.0$ & $0.0014-24.25$ & 1267.6 \\
\hline 1-in. MESL, thaw & 9000 & 0.0103 .5 .75 & $0.0064-12.0$ & $0.0047-15.25$ & $0.0039-18.875$ & $0.0028-24.375$ & 837,8 \\
\hline 5-in. MESL thaw & 8835 & $0.0136-5.75$ & $0.0098-11.5$ & $0.0069 \cdot 14.25$ & $0.0055-18.0$ & 0.0037 .23 .5 & 649.6 \\
\hline 12-in. MESL thaw & 9000 & 0.0188 .5 .5 & $0.0138-11.5$ & $0.0097-14.75$ & $0.0075-17.75$ & $0.0053-23.25$ & 478.7 \\
\hline 17.in. MESL thaw & 9000 & $0.0229-5.5$ & $0.0161-11.0$ & $0.0110-14.25$ & $0.0088-17.5$ & $0.0056-23.5$ & 393.0 \\
\hline 20-in, MESL thaw & 9000 & $0.0248-5.5$ & 0.0167 .11 .25 & $0.0126-14.5$ & $0.0101-17.5$ & $0.0062-23.5$ & 362.9 \\
\hline Complete MESL thaw & 9000 & $0.0303-5.25$ & $0.0207-11.25$ & $0,0143-14.5$ & $0.0110-17.625$ & $0,0064-23,5$ & 297.0 \\
\hline 3 wk after thawing & 9000 & $0.0293-5.875$ & 0.0193 .12 .0 & $0.0128-15.75$ & $0.0097-18.25$ & 0.0054 .24 .5 & 307.2 \\
\hline
\end{tabular}

held nearly constant because of little or no frozen pore water. Some stiffness decrease in all sections during thawing can be attributed to an increase in the temperature of the asphalt concrete.

Figure 13 illustrates the Benkelman beam deflections during two thaw periods. Resilient stiffness values from the maximum deflections are plotted in Figure 12. The plain silt section $(G)$ had the greatest deflection of the three MESL sections. The non-encapsulated section, with lime/fly ash stabilized silt (I), had the greatest deflection during the first thaw season. However, by the third thaw season it had gained a strength, presumably with the curing of the additive, greater than the plain and salt-stabilized silt sections ( $G$ and F). Figure 12 also shows the smaller strength gain of the salt-stabilized silt during the extreme low temperatures. The greater resilient stiffness in February is considered to be due to a lower asphalt pavement temperature. In general, the frozen moduli are lower in the outdoor sections than in the controlled environment, probably because of the lower water content in the outdoor sections.

Figure 14 shows a decrease by an order of magnitude in the resilient modulus with increased temperature for the $\mathrm{AC}-20$ asphalt concrete. The plain AC-1,5 asphalt concrete shows an eight-fold decrease in resilient modulus 
Table III. Resilient surface deformations and resilient deformation stiffness of access road MESL test sections.

\begin{tabular}{|c|c|c|c|c|c|c|c|c|}
\hline Section & Thaw condition & $\begin{array}{c}\text { Load } \\
(l b)\end{array}$ & Deformat & ion (in.) - Offse & $t$ from center of & 12-in.-diam load & plate (in.) & $\begin{array}{l}\text { Resilient } \\
\text { stiffness } \\
\text { (kips/in.) }\end{array}$ \\
\hline \multirow{4}{*}{$\begin{array}{l}\text { F:NaCl- } \\
\text { stabilized } \\
\text { silt MESL } \\
\text { w/AC- } 1.5 \\
\text { conc }\end{array}$} & $\begin{array}{l}\text { Partially frozen } \\
24 \text { Feb } 76\end{array}$ & 8750 & $0.0354-5.875$ & $0.0133-12.125$ & $0.0081-18.375$ & $0.0054-18.375$ & $0.0030-24.0$ & 247.2 \\
\hline & $\begin{array}{l}\text { Completely thawed } \\
29 \text { Mar } 76\end{array}$ & 8500 & $0.0610-5.5$ & $0.0250-11.5$ & $0.0151-14.75$ & $0.0110-18.25$ & & 139.3 \\
\hline & $\begin{array}{l}\text { Completely thawed } \\
29 \text { Apr } 76\end{array}$ & 8750 & $0.0497-5.75$ & $0,0270-10,0$ & $0.0162-13,25$ & $0.0109-16.375$ & $0.0072-22.625$ & 176.1 \\
\hline & $\begin{array}{l}\text { Completely thawed } \\
2 \text { June } 76\end{array}$ & 8750 & $0.0549-5.37$ & $0.0184-11.25$ & $0.0110-14.25$ & $0.0079-17.25$ & $0.0047-23.0$ & 159.4 \\
\hline \multirow{4}{*}{$\begin{array}{l}\text { G:silt } \\
\text { MESL } \\
\text { w/AC-1.5 } \\
\text { conc }\end{array}$} & $\begin{array}{l}\text { Partially frozen } \\
24 \text { Feb } 76\end{array}$ & 8375 & $0.0098-5.5$ & $0.0047-11.5$ & $0.0037-14.5$ & $0.0031-17.75$ & $0.0025-23.5$ & 854.6 \\
\hline & $\begin{array}{l}\text { Completely thawed } \\
29 \text { Mar } 76\end{array}$ & 8500 & $0.0968-5.875$ & $0.0552-12.5$ & $0.0413-15.5$ & $0.0289-19.0$ & $0.0160-24.5$ & 87.8 \\
\hline & $\begin{array}{l}\text { Completely thawed } \\
29 \mathrm{Apr} 76\end{array}$ & 9000 & $0.0683-5.125$ & $0.0373-10.25$ & $0.0214-13.75$ & $0.0145-16.75$ & $0.0078-23.25$ & 131.8 \\
\hline & $\begin{array}{l}\text { Completely thawed } \\
29 \text { June } 76\end{array}$ & 8500 & $0.0679-5.75$ & $0.0253-11.0$ & & $0.0107-17.75$ & $0.0067-23.5$ & 125.2 \\
\hline \multirow{4}{*}{$\begin{array}{l}\text { H:Lime/ } \\
\text { fly ash- } \\
\text { stabilized } \\
\text { silt MESL } \\
\text { w/AC-1.5 } \\
\text { conc } \\
\text { (asbestos- } \\
\text { stabilized) }\end{array}$} & $\begin{array}{l}\text { Partially frozen } \\
24 \text { Feb } 76\end{array}$ & 8625 & $0.0037-6.25$ & $0.0030-11.5$ & $0.0024-14.5$ & $0.0022-17.75$ & $0.0019-23.75$ & 1287.3 \\
\hline & $\begin{array}{l}\text { Completely thawed* } \\
29 \text { Mar } 76\end{array}$ & 8625 & $0.0327-6.0$ & $0.0196-12.0$ & $0.0148-15.25$ & $0.0124-18.25$ & $0.0091-24.25$ & 263.8 \\
\hline & $\begin{array}{l}\text { Completely thawed } \\
29 \text { Apr } 76\end{array}$ & 9000 & $0.0209 \cdot 5.25$ & $0.0140-10.375$ & $0.0105-14.0$ & $0.0083-17.25$ & $0.0054-23.5$ & 430.6 \\
\hline & $\begin{array}{l}\text { Completely thawed } \\
2 \text { June } 76\end{array}$ & 9000 & $0.0220-5.75$ & $0.0126-11.5$ & $0.0095-15.0$ & $0.0075-18.0$ & $0.0048-23.5$ & 409.1 \\
\hline
\end{tabular}

AC- 1.5 at $27^{\circ} \mathrm{F}$.
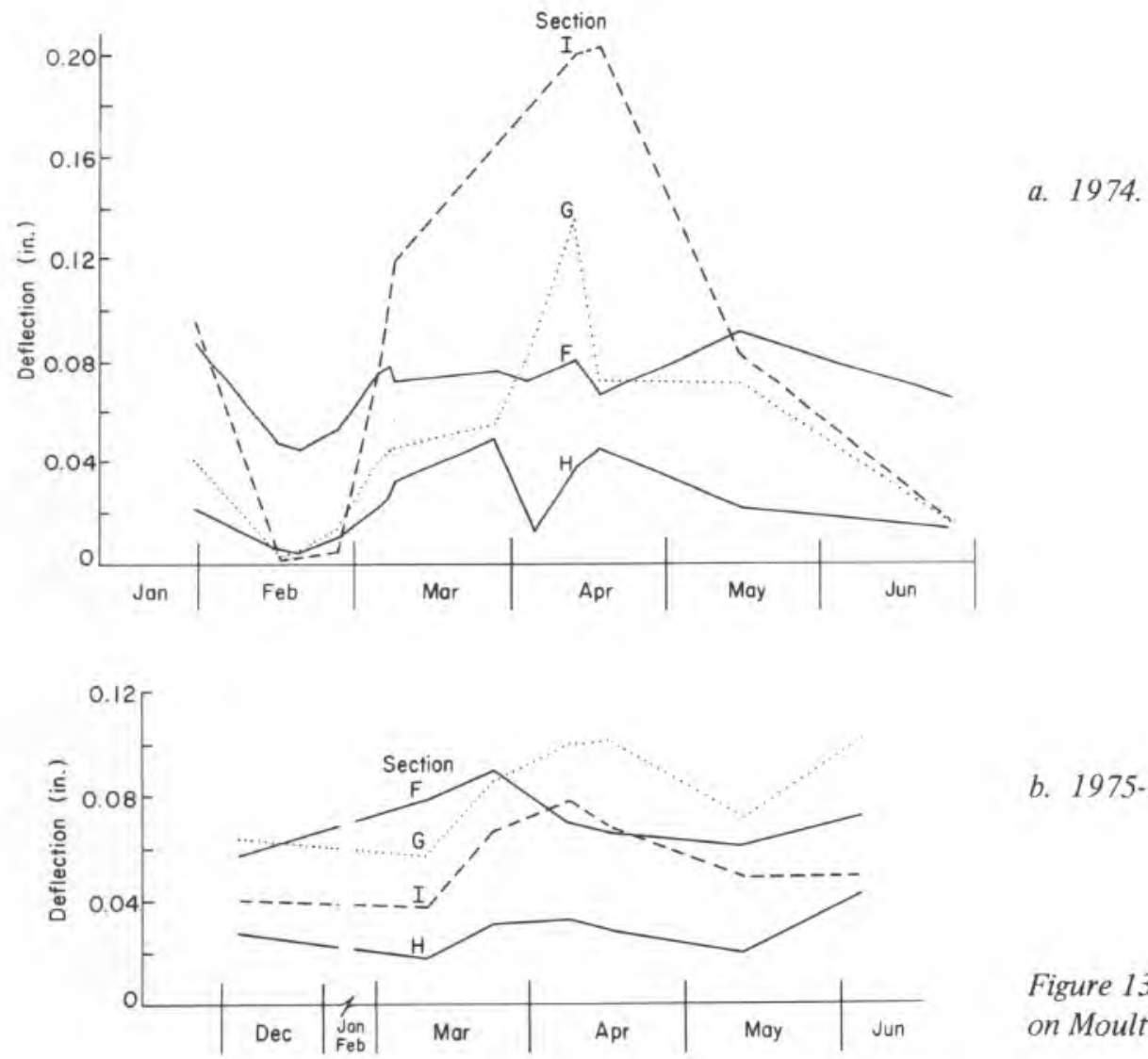

b. $1975-1976$.

Figure 13. Benkelman beam deflections on Moulton pit silt MESL (access road). 
Table IV. Resilient deformation moduli for Moulton pit silt MESL test section - first freeze-thaw cycle.

$\mathrm{M}_{\mathrm{r}}=$ resilient modulus, $\mu=$ Poisson's ratio from analysis.

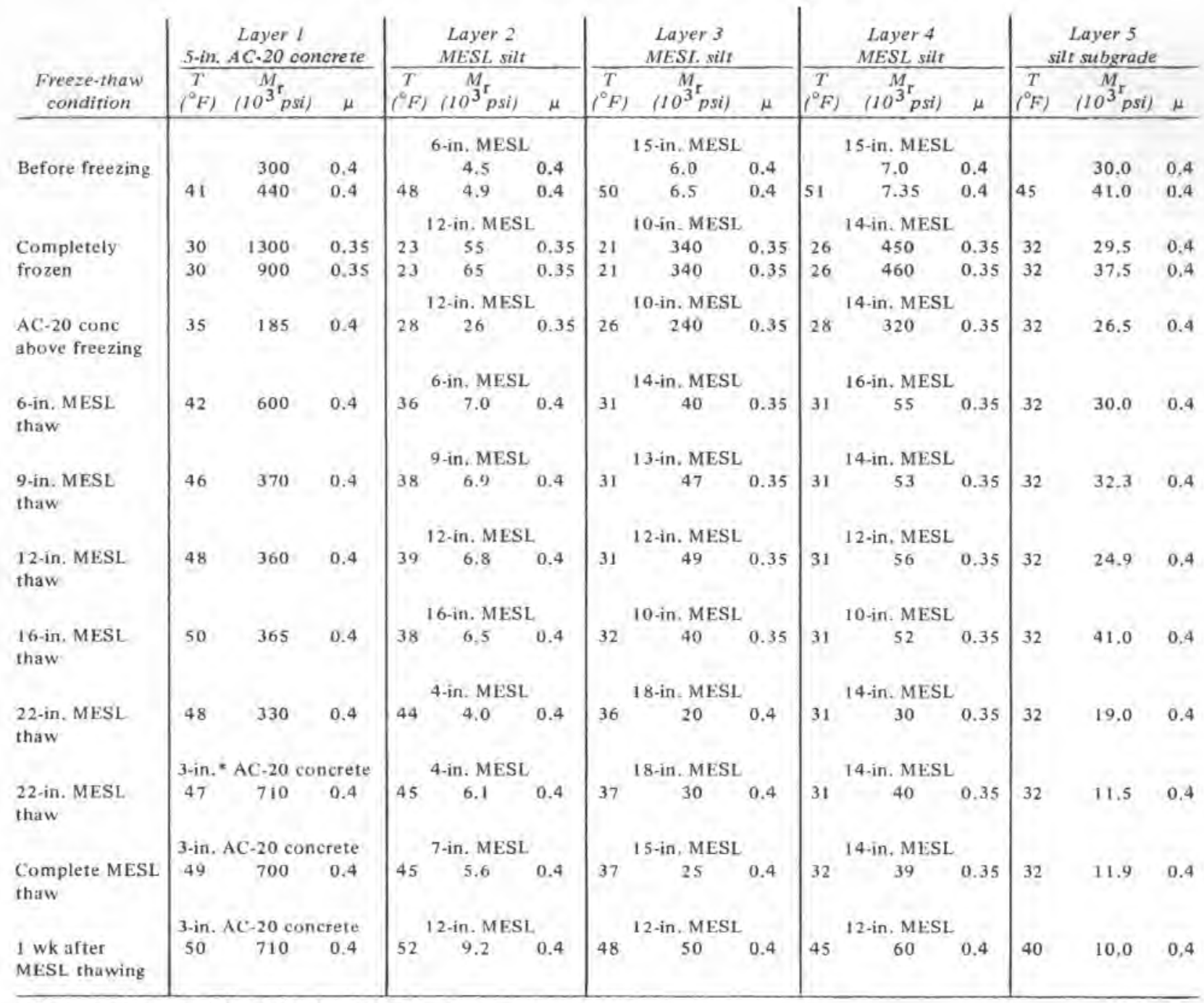

- Three tests run at different location with thinner pavement.

but the results for the same concrete with the asbestos additive suggest a possible stability of the resilient modulus in the temperature range of 40 to $100^{\circ} \mathrm{F}$,

The modulus values for the silt subgrade below the MESL in the controlled environment sections ranged from 10,000 psi to 58,000 psi for the two freeze-thaw cycles. The lower values were calculated for deep and complete thaw conditions on the first freeze-thaw cycle and probably reflect a higher soil moisture content. A modulus value of $30,000 \mathrm{psi}$ was the average for the unfrozen silt subgrade at a moisture content of about $17 \%$ (Fig. 6b). Jones and Witczak ${ }^{6}$ have also indicated high variations in subgrade moduli between and within test sections on the San Diego test road. The average thawed modulus value for the outside environment subgrade was about 20,000 psi and the partially frozen value was about $42,000 \mathrm{psi}$.

Indications in Figure 15 are that the thickness of the thawed layers used in the Chevron program has no effect on the resilient modulus of the first layer beneath the pavement (layer 2) in the thickness range of 1 to 20 inches. The absence of moisture migration in the MESL soil as seen in Figure 6 would lead one to accept this as reasonable. There is much scatter in the values for the second layer beneath the pavement (layer 3) but a slight tendency for higher values with greater thickness exists. The values for the layer on the subgrade (layer 4) tend to be higher for lesser thickness, 
Table V. Resilient deformation moduli for Moulton pit silt MESL test section - second freeze-thaw cycle.

$M_{r}=$ resilient modulus, $\mu=$ Poisson's ratio from analysis.

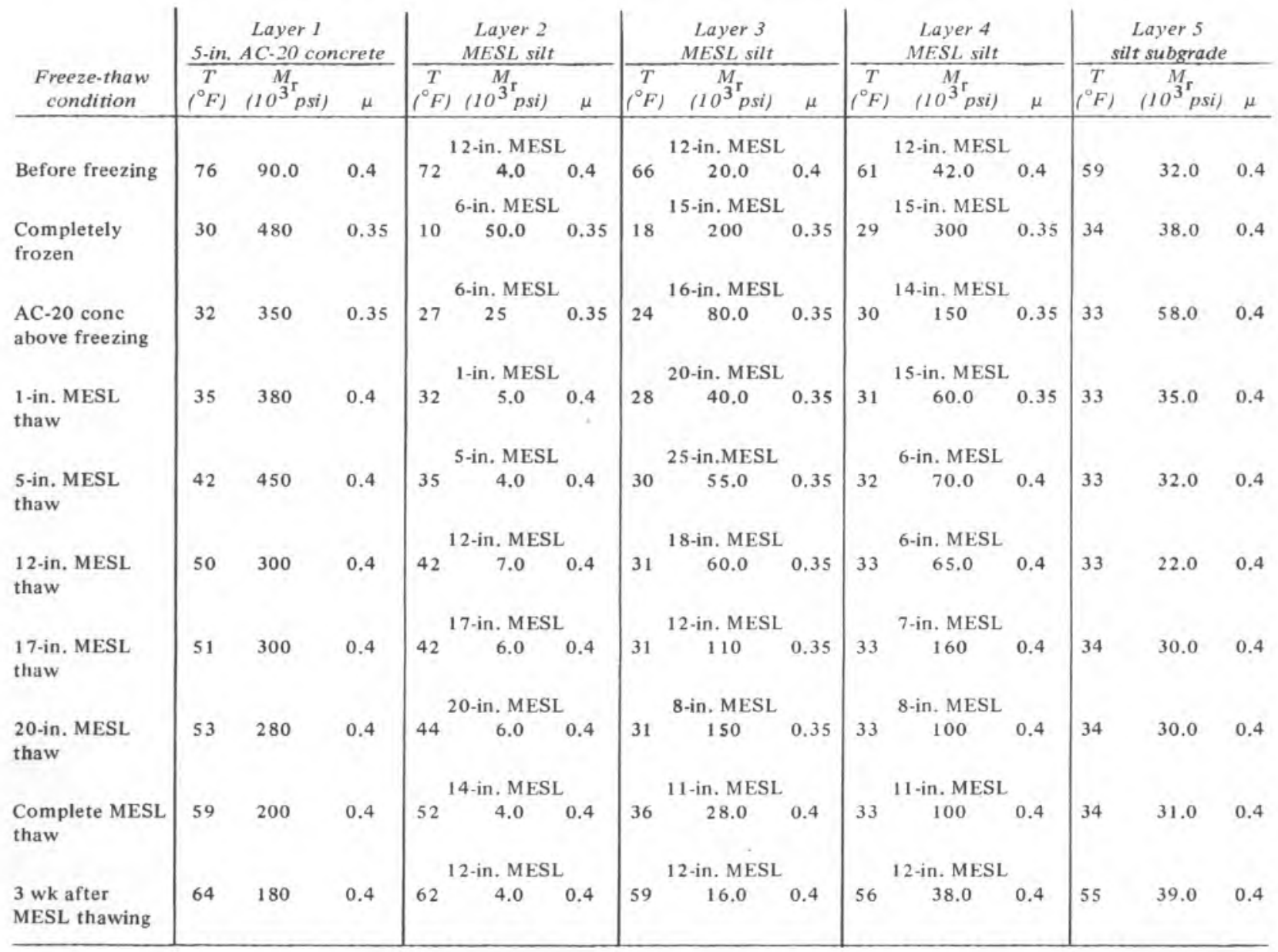

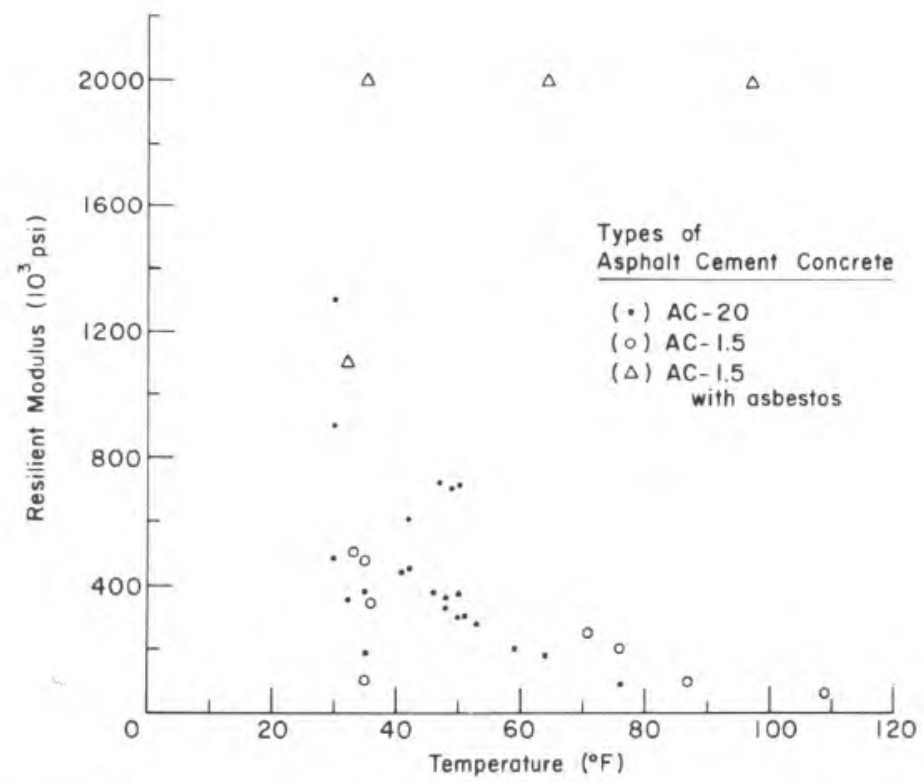

Figure 14. Variation of resilient deformation modulus of asphalt cement concrete with temperature. 
Table VI. Resilient deformation moduli for access road MESL test sections.

$M_{r}=$ resilient modulus, $\mu=$ Poisson's ratio from analysis.

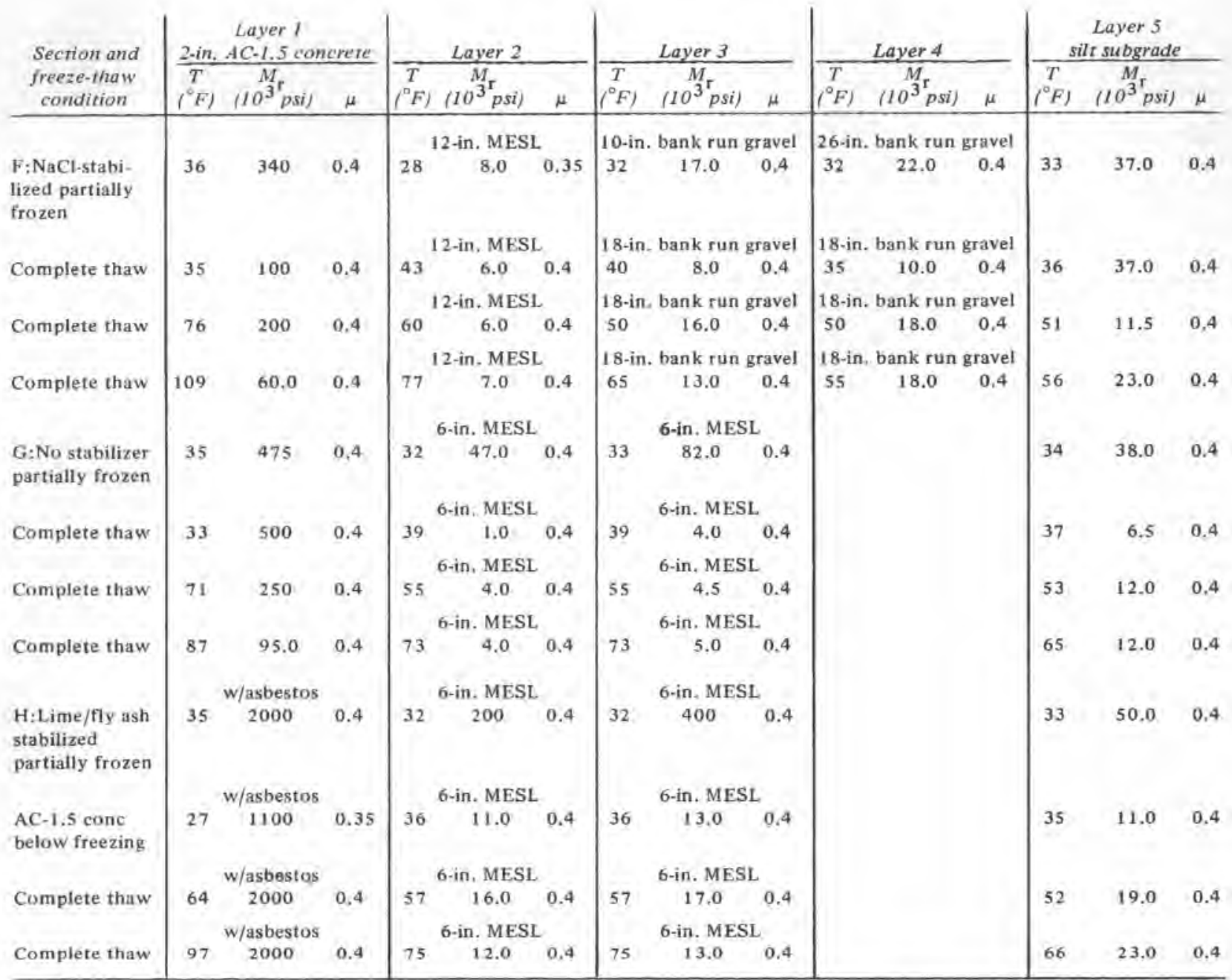

which is probably due to a lower stress intensity at greater depth in the section.

An attempt at relating resilient modulus with temperature in the frozen silt MESL layers is shown in Figure 16. Again, the values for the first layer beneath the pavement seem to remain constant in the temperature range of 10 to $28^{\circ} \mathrm{F}$. Many of the values for the second and third layers beneath the pavement are in the same range at about $31^{\circ} \mathrm{F}$. The higher values for these layers are probably also due to lower stress intensities.

\section{CONCLUSIONS}

Meaningful resilient deformation modulus values for individual layers of a layered pavement system can be determined from resilient surface deflection measurements for repetitive plate bearing tests using the Chevron n-layered elastic analysis. The resilient deformation modulus values for AC-20 asphalt concrete ranged from $1,200,000$ psi at $25^{\circ} \mathrm{F}$ to 90,000 psi at $76^{\circ} \mathrm{F}$. The values for AC-1.5 asphalt concrete ranged from 500,000 psi at $28^{\circ} \mathrm{F}$ to $60,000 \mathrm{psi}$ at $109^{\circ} \mathrm{F}$. Additional tests on $\mathrm{AC}$ 1.5 asphalt concrete with asbestos should be conducted to determine the strength-temperature relationship.

Resilient deformation modulus values of thawed en. capsulated silt ranged from $5,000 \mathrm{psi}$ for near-surface layers to $160,000 \mathrm{psi}$ for layers on the subgrade. The values for the thawed non-encapsulated silt subgrade ranged from 20,000 to 30,000 psi depending on water content. The values for frozen silt ranged from about $50,000 \mathrm{psi}$ for near-surface layers to $450,000 \mathrm{psi}$ for layers on the subgrade. 


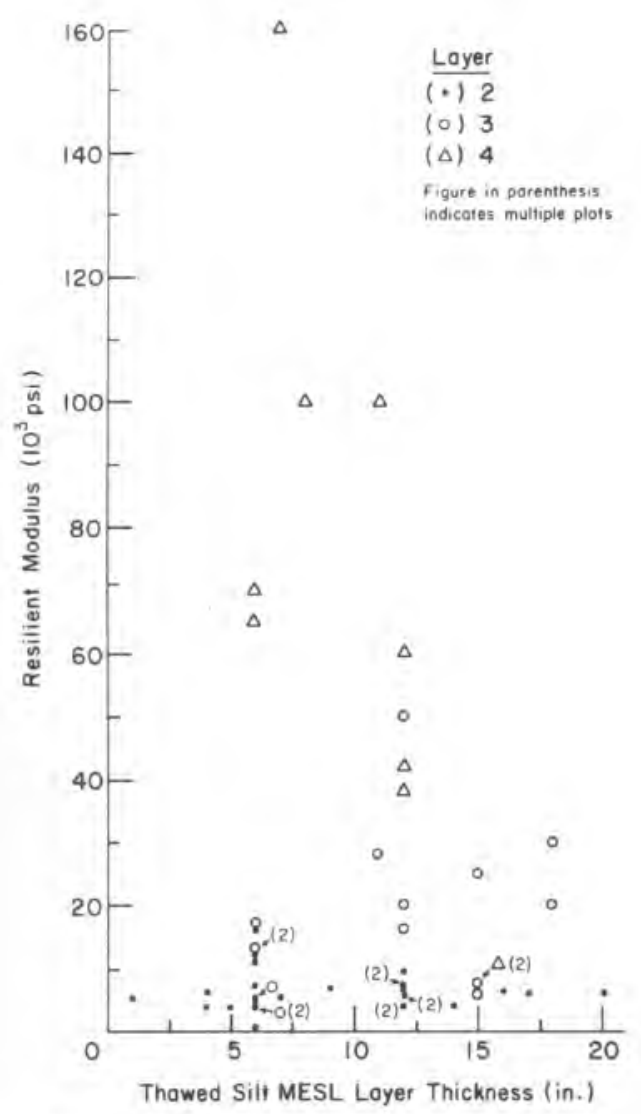

Figure 15. Variation of resilient deformation modulus of thawed silt MESL layer with thickness.

The resilient deformation modulus for the frozen encapsulated silt layers at nearly equal shallow depths below the surface is constant at about $40,000 \mathrm{psi}$ in the temperature range of $10^{\circ} \mathrm{F}$ to $32^{\circ} \mathrm{F}$ for these relatively low moisture contents.

The resilient deformation modulus for the thawed encapsulated silt layers is essentially independent of layer thickness in the thickness range of 1 to 20 inches.

Resilient deformation stiffness values for the complete pavement system computed from repetitive plate bearing tests and Benkelman beam tests are nearly equal during the critical thaw period. The resilient deformation stiffness suffers a six-fold decrease as thaw depth below the AC-20 asphalt concrete increases from 0 to 36 inches.

Soil moisture migration was not a problem in the membrane-enveloped silt at moisture contents equivalent to about $75 \%$ saturation for the CE- 12 compaction effort.

When utilizing fine-grained soils by the membraneenveloping technique, the problem of moisture migration is less important at a given moisture content if

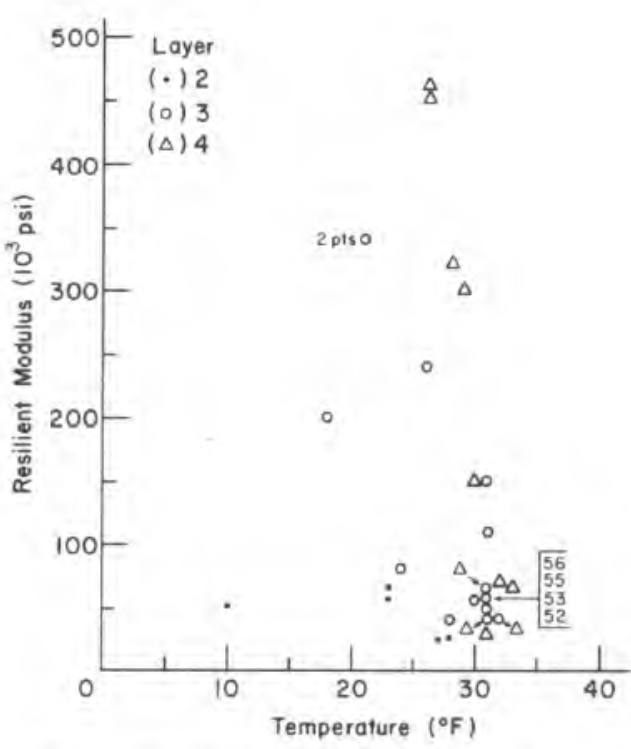

Figure 16. Variation of resilient deformation modulus of frozen silt MESL layer with temperature.

the required compaction effort is less because the degree of saturation is lower for lower densities.

More heavily loaded pavement systems will require high density and low moisture content MESL's if placed near the surface, while lower density and higher moisture content MESL's can be utilized at greater depths or in more lightly loaded pavements.

\section{LITERATURE CITED}

1. Arctic Construction and Frost Effects Laboratory, U.S. Army Corps of Engineers (1958) Frost investigations, cold room studies, Third Interim Report of Investigations. ACFEL Technical Report 43.

2. Berg, R.L. and R.A. Eaton (1974) Construction and first winter's performance of the experimental USA CRREL access róad. CRREL Internal Report 408 (unpublished).

3. Burns, C.D. and W.N. Brabston (1968) Membrane-envelope technique for waterproofing soil base courses for airstrips - Bare base support. U.S. Army Waterways Experiment Station Miscellaneous Paper S-68-13.

4. Department of Defense (1964) Test method for pavement subgrade, subbase, and base course materials. MIL STD 621A. 
5. Eaton, R., J. Stubstad and R. Redfield (1976) The CRREL controlled environment pavement test facility. U.S. Army Cold Regions Research and Engineering Laboratory Technical Note (unpublished).

6. Jones, M.P. and M.W. Witczak (1977) Analysis of the subgrade modulus on the San Diego test road. Annual Meeting of the Transportation Research Board, January.

7. Michelow, J. (1963) Analysis of stresses and displacements in an n-layered elastic system under a load uniformly distributed on a circular area. California Research Corporation, Richmond, Calif.

8. Peyton, H.R., C.F. Kennedy and J.W. Lund (1966) Stabilization of silty soils in Alaska - Phase III. University of Alaska Arctic Environmental Engineering Laboratory Research Report No. 3 for the Alaska Department of Highways-United States Bureau of Public Roads (cooperating).

9. Quinn, W.F., D. Carbee and T.C. Johnson (1973) Membrane encapsulated soil layers (MESL) for road construction in cold regions. Symposium on Frost Action in Roads, Oslo, Norway. Published by Organization for Economic Co-operation and Development, Paris.

10. Requirements for constructing membrane-enveloped soil layers (MESL) in cold regions. CRREL, 1973.

11. Smith, N. and D.A. Pazsint (1975) Field test of a MESL (membrane-enveloped soil layer) road section in central Alaska. CRREL Technical Report 260.

12. Smith, N. and J.A. Groves(1976) Analysis of flexible pavement resilient surface deformations using the Chevron layered elastic analysis computer program. Symposium on Non-destructive Test and Evaluation of Airport Pavement, U.S. Army Engineer Waterways Experiment Station.

13. The Asphalt Institute (1974) Specifications for paving and industrial asphalts. Specification Series No. 2 (SS-2), 1974-75 Edition.

14. U.S. Department of Transportation, Federal Highway Administration, Offices of Research and Development, Implementation Division (1974) Users' manual for membrane encapsulated pavement sections (MEPS). Implementation Package 74-2.

15. Warren, H. and W.L. Dieckmann (1963) Numerical computations of stresses and strains in a multiple-layered asphalt pavement system. California Research Corporation, Richmond, Calif. 